\title{
METODE PEMBENTUKAN ESQ ANAK DALAM KELUARGA MENURUT PENDIDIKAN ISLAM
}

\author{
Abdul Basyit \\ basyit71@yahoo.com \\ (Dosen Fakultas Agama Islam, Universitas Muhammadiyah Tangerang)
}

\begin{abstract}
Abstrak:
Tujuan pendidikan dalam keluarga tiada lain agar anak mampu berkembang secara maksimal, baik jasmani, akal, maupun ruhaninya. Terdapat beberapa metode yang dapat diterapkan oleh keluarga untuk memaksimalkan potensi keluarga untuk membentuk multikecerdasan (ESQ) anak. Dalam pelaksanaan proses pendidikan anak, metode yang diterapkan haruslah bervariasi sesuai dengan kebutuhan, situasi, kondisi, tempat, dan waktu si anak. Metode yang dimaksud terdiri dari 1) Metode pembelajaran komunikatif, 2) Metode keteladanan, 3) Metode pembiasaan, 4) Metode pembelajaran langsung, dan 5) metode penghargaan dan hukuman.
\end{abstract}

\section{Kata Kunci: Pembentukan ESQ, Keluarga, Pendidikan Islam.}

\section{A. Pendahulun}

Pesatnya arus globalisasi dan semakin canggihnya perkembangan ilmu pengetahuan dan teknologi telah memberikan dampak besar bagi kemajuan peradaban manusia. Namun sejalan dengan hal tersebut ekses negatif pun bermunculan di hadapan manusia, baik secara individual maupun secara kolektif. Ekses negatif dimaksud muncul dalam berbagai bentuk, misalnya kenakalan remaja, tawuran antarpelajar, penyalahgunaan narkotika, pergaulan bebas, penyimpangan seksual, dan meningkatnya jumlah pasien penyakit psikologis (seperti stress, depresi, atau stroke). Hal tersebut kemudian berpengaruh pula terhadap kemapanan dan tatanan masyarakat damai sebagaimana dicita-citakan oleh tujuan peradaban itu sendiri.

Menurut Zakiyah Darajat, ${ }^{1}$ dalam pendidikan keluarga ini, orang tua sangat berperan dan mereka diminta tanggung jawab, komitmen, dan konsistensinya

${ }^{1}$ Zakiyah Darajat, Berawal dari Keluarga: Revolusi Belajar Cara al-Qur'an, Jakarta, Hikmah, 2002, cetakan ke-1, hlm. xi. dalam pendidikan anak. Dengan demikian, tanggung jawab orang tua (keluarga) dalam pendidikan anak cukup signifikan, sebab keluarga merupakan lingkungan yang pertama kali bersentuhan dengan anak. Dari mereka pula lah, anak memperoleh pengetahuan, pengalaman, keterampilan, dan sikap. Oleh karena itu, kualitas orang tua dan lingkungan keluarga sangat dominan dalam pembentukan jiwa dan kerpibadian anak.

Tujuan pendidikan dalam keluarga tiada lain agar anak mampu berkembang secara maksimal, baik jasmani, akal, maupun ruhaninya. $^{2}$ Dengan perkembangan yang optimal tersebut diharapkan akan terbentuk kecerdasan anak dalam berbagai bentuknya. Akhirnya anak akan mampu berperan sebagai anggota masyarakat yang baik dan juga sanggup mempertanggungjawabkan segala perilakunya sebagai khalîfat Allâh dan

${ }^{2}$ Abd al-Rahmân al-Nahlawi, Pendidikan Islam di Rumah, Sekolah, dan Masyarakat, Terjemahan oleh Sihabuddin, Jakarta, Gema Insani Press, 1995, hlm 27. 
'Abd Allâh. Untuk itu, orang tua dan lingkungan keluarga harus mampu menciptakan lingkungan yang dapat menjamin berkembangnya seluruh potensi dan kemampuan seorang anak. ${ }^{3}$

\section{B. Pengertian Keluarga}

Dalam al-Qur'an, kata keluarga ${ }^{4}$ ini ditunjukkan oleh tiga kata dominan yaitu $a h l$, alli, dan 'asyir. Beberapa kata ahl yang merujuk pada pengertian $\mathrm{k}$ dhamîr, seperti ahlahâ, ahlikum, ahlunâ, eluarga, secara spesifik diikuti denganahlahu, ahlihim, dan ahlihinna.. ${ }^{5}$ Contohnya terdapat dalam QS al-Tahrîm (66):6:

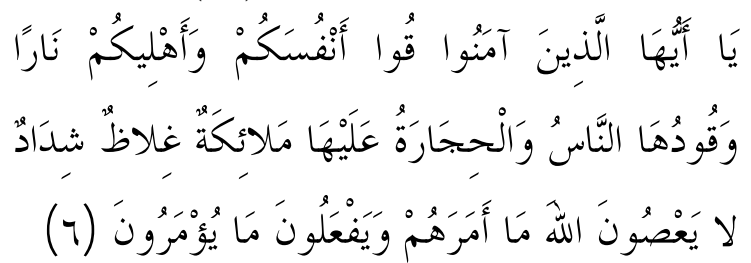

Hai orang-orang yang beriman, pelaharalah dirimu dan keluargamu dari api neraka yang bahan bakarnya adalah manusia dan batu. Penjaganya malaikatmalaikat yang kasar, yang keras, yang tidak mendurhakai Allah terhadap apa yang diperintahkan-Nya kepada mereka

${ }^{3}$ Zakiyah Darajat, Berawal dari Keluarga: Revolusi Belajar Cara al-Qur'an, Jakarta, Hikmah, 2002, cetakan ke-1, hlm. xi.

${ }^{4}$ Menurut Abu Ahmadi, keluarga berasal dari kata kawula dan warga. Kawula berarti abdi, yakni hamba, sedangkan warga berarti anggota. Kata keluarga ini menyiratkan posisi dan kedudukan setiap individu di dalam ikatan yang disebut keluarga tersebut, yaitu sebagai abdi dan warga. Sebagai abdi di dalam keluarga, seseorang wajib menyerahkan segala kepentingan kepada keluarganya dan sebagai warga atau anggota, ia berhak untuk ikut mengurus segala kepentingan di dalam keluarganya (Abu Ahmadi, Ilmu Pendidikan, Jakarta: Rineka Cipta, 1991, hlm. 176).

${ }^{5}$ Muhammad Fu'ad Abd al-Baqî, Mu'jam alMufahrats li Alfadz al-Qur'ân al-Karîm, Angkasa, t.t., hlm. 96-97. dan selalu mengerjakan apa yang diperintahkannya [al-Tahrîm (66):6].

Namun tidak semua kata-kata tersebut berkaitan dengan makna keluarga. Kata ahl misalnya tidak semua merujuk pada arti keluarga, seperti terdapat dalam frase ahl al-kitâb, ahl al-injîl, ahl al-qurâ, ahl al-madînah, ahl al-bait, ahl al-dzikrâ, ahl al-madyân, ahl al-nâr, al-maghfirah, dan ahl al-taqwâ. Sementara itu kata âli, umumnya diikuti dengan nama-nama nabi dan lainnya, seperti âli Musâ, âli Imrân, âli Hârûn, âli Dâwûd, âli Ibrâhîm, âli Ya'qûb, âli Lûth, dan âli Fir'aûn. Penisbahan ini menunjukkan siapa yang termasuk ke dalam keluarga dari Nabi-nabi tersebut dan lainnya.

Sedangkan, kata 'asyîr diartikan dengan bergaul, kawan, golongan, kerabat, unta, sepuluh, dan dua puluh. Dalam alQur'an, kata ini ditampilkan dalam berbagai bentuk kata, yaitu 'asyîratuhum, 'asyiruhunna, al-'asyîr, 'asyîrataka, 'asyîratukum, al-'isyar, ma'syar, dan 'isyr. Dari kata-kata tersebut, kata yang menunjukkan makna keluarga adalah 'asyîratuhum dan 'asyîratukum. ${ }^{6}$

Dalam Kamus Besar Bahasa Indonesia, kata keluarga berarti ibu, bapak, dan anak-anak, seisi rumah, serta orang seisi rumah yang menjadi tanggungan. ${ }^{7}$ Berdasarkan pengertian ini, maka ruang lingkup keluarga itu adakalanya terdri dari suami, istri, dan anak. Komposisi ini dikenal dengan istilah keluarga inti atau keluarga batih. Sedangkan keluarga yang hanya terdiri dari suami dan istri tanpa

${ }^{6}$ Muhammad Fu'ad Abd al-Baqî, Mu'jam alMufahrats li Alfadz al-Qur'ân al-Karîm, Angkasa, t.t., hlm. 96-97 dan 462.

${ }^{7}$ Depdikbud, Kamus Besar Bahasa Indonesia, Jakarta: Balai Pustaka, 1990), cet ke-3, halaman 267 
anak dinanamakan dengan keluarga parsial. Selain itu ada pula ruang lingkup keluarga yang sifatnya lebih umum, yaitu keluarga bilateral, keluarga luas, dan keluarga paternal. Keluarga bilateral didasarkan pada hubungan kekerabatan dari pihak ayah dan dari pihak ibu. Sedangkan keluarga luas merupakan satuan kerabat yang terdiri dari atas beberapa orang yang berasal dari kerabat dekat suami atau istri. Sedangkan keluarga paternal adalah hubungan kekerabatan yang hanya diperhubungkan dari kerabat ayah. $^{8}$

Keluarga merupakan unit sosial terkecil dalam kehidupan umat manusia. Ia merupakan suatu sistem kehidupan masyarakat terkecil yang dibatasi adanya keturunan (nasab). Dalam konsep keluarga muslim, keluarga juga dapat berkaitan dengan konsep ummah sebagai akibat adanya kesamaan agama. ${ }^{9}$ Ia merupakan lingkungan pertama dalam masyarakat tempat terjadinya awal proses sosialisasi dan perkembangan individu. Dari sudut pandang pedagogis, menurut Zakiyah Darajat, keluarga merupakan suatu persekutuan hidup yang dijalani oleh kasih sayang antara pasangan dua jenis manusia yang dikukuhkan dengan pernikahan, yang

\footnotetext{
${ }^{8} \mathrm{Abu}$ al-Ati melihat adanya dua posisi dalam struktur kelurga menurut Islam, yaitu posisi utama (primary) dan posisi tambahan (suplementary), yang keduanya saling melengkapi sebagai satu bangunan keluarga dalam Islam. Posisi utama adalah keluarga dalam tingkatan pertama yang terdiri dari keluarga batih (ayah, ibu, dan anak). Posisi tambahan adalah keluarga pada tingkatan kedua, yang terdiri dari anggota dari keturunan ayah dan ibu baik ke samping (horisontal) maupun ke atas (vertikal) dan keluarga karena persamaan agama.

${ }^{9}$ Ramayulis dkk, Pendidikan Islam dalam Rumah Tangga, Jakarta, Kalam Mulia, 1996, hlm. 29
}

dimaksudkan sebagai media untuk saling menyempurnakan diri. ${ }^{10}$

\section{Metode Keluarga dalam Upaya Pembentukan ESQ Anak dalam Pendidikan Islam}

Membentuk kecerdasan emosional dan spiritual (ESQ) anak memerlukan metode yang tepat, beragam, dan terus berkembang sesuai dengan kebutuhan anak. Metode yang dimaksud pada bagian ini adalah serangkaian cara yang terencana, integral (satu kesatuan), sistematis, dan bertahap dalam upaya membentuk kecerdasan anak, baik kecerdasan intelektual, emosional, maupun spiritual. Beberapa metode dapat diadaptasi dari perkembangan mutakhir dalam belajar, terutama dalam penemuan metode quantum. ${ }^{11}$ Metode yang dimaksud terdiri dari 1) Metode pembelajaran komunikatif, 2) Metode keteladanan, 3) Metode pembiasaan, 4) Metode pembelajaran langsung, dan 5) metode penghargaan dan hukuman. Kelima metode tersebut akan dibahas secara terinci pada paparan berikut.

\section{Metode Pembelajaran Komunikatif}

Proses pembelajaran pada dasarnya adalah seluruh perbaikan dan perubahan yang terjadi atas kelakuan. ${ }^{12}$ Bagaimanapun ujung dari belajar dan pembelajaran. ${ }^{13}$ Membentuk kecerdasan

${ }^{10}$ Zakiyah Darajat, Berawal dari Keluarga: Revolusi Belajar Cara al-Qur'an,. Jakarta, Hikmah, hlm. 14.

${ }^{11}$ Lihat misalnya, Bobbi DePorter, Quantum Learning, Bandung, Kaifa, 1999.

${ }^{12}$ Zakiyah Darajat, Kepribadian Guru, Jakarta, Bulan Bintang, 1980, hlm. 25.

${ }^{13}$ Untuk pengertian belajar dan pembelajaran dapat dilihat dalam Dimyati dan Mudjiono, Belajar dan Pembelajaran, Jakarta, Rineka Cipta dan Depdikbud, 2002, hlm. 1-17. 
emosional dan spiritual (ESQ) anak hanya dapat efektif apabila dilakukan dengan pembelajaran interaktif atau komunikatif. Model pembelajaran ini merupakan pembelajaran yang bersifat dialogis di mana anak tidak merasa diajari, dipaksa, atau didoktrin tanpa adanya proses pemahaman dan penalaran yang diperoleh anak. Dalam model pembelajaran ini anak hanya diberi stimulus dan diberi keleluasaan untuk pencarian pengetahuan dan pengalamannya secara bebasbertanggung jawab. Pola asuh otoritatifdemokratis menjadi penting untuk mengembangkan kreativitas anak. Dengarkan perkataan anak, dorong anak untuk berani mengucapkan pendapatnya, hargai pendapat anak, jangan memotong pembicaraan anak, jangan memaksakan pendapat orang tua atau melecehkan pendapat anak. Rangsanglah anak untuk tertarik mengamati dan mempertanyakan tentang berbagai hal di lingkungannya, beri kebebasan dan dorongan untuk mengembangkan khayalan, merenung, berfikir, mencoba dan mewujudkan gagasan. Berikan pujian untuk hasil yang telah dicapainya walau sekecil apapun. Jangan menghentikan rasa ingin tahu anak, jangan banyak mengancam atau menghukum, beri kesempatan untuk mencoba, asalkan tidak membahayakan dirinya atau orang lain.

Dalam hal ini, menurut Jalaluddin Rakhmat, ${ }^{14}$ hendaknya para orang tua mampu menjadikan diri mereka sebagai gembala spiritual dan emosional anak. Orang tua (atau guru) yang bermaksud mengembangkan ESQ anak haruslah seseorang yang sudah mengalami

\footnotetext{
${ }^{14}$ Jalaluddin Rakhmat, Belajar Cerdas, MLC, 2005, hlm. 38 .
}

kesadaran emosional dan spiritual juga. Betapa banyaknya perilaku manusia yang terilhami oleh orang-orang yang sekarang dikenal sebagai orang yang ber-ESQ tinggi, baik orang-tua, guru, atau orangorang kecil di sekitar anak. ${ }^{15}$ Sebagai contoh dari pembelajaran komunikatif ini, penulis paparkan tiga aktivitas yang dapat ditempuh orang tua dalam membentuk ESQ anak.

\section{a. Membaca Kitab Suci}

Sejak dini, orang tua telah sejak dini memperkenalkan anaknya untuk membaca Kitab Suci. Perkembangan terakhir dalam upaya pembelajaran membaca al-Qur'an seperti metode Iqra dapat membantu setiap anggota keluarga untuk dapat membaca alQur'an secara cepat. Hanya saja seringkali, orang tua dan guru sudah merasa cukup ketika anaknya sudah mampu membaca alQur'an, sekalipun tidak diikuti pemaknaan. Oleh karena itu, seharusnya pendidikan membaca, harus diikuti dengan pendidikan pemahaman dan pengamalan ayat-ayat suci. Untuk memotivasi anak, dapat pula diceritakan kepada anak tentang hubungan orang-orang besar dengan al-Qur'an.

\section{b. Menceritakan Kepada Anak Ceritera yang Baik-baik}

Dalam pembelajaran komunikatif ini, orang tua dapat menceritakan kisah-kisah agung. Anak-anak, bahkan orang dewasa, sangat terpengaruh dengan cerita. "Manusia," kata Gerbner, "adalah satusatunya makhluk yang suka bercerita dan hidup berdasarkan cerita yang dipercayainya." Para Nabi mengajar umatnya dengan parabel atau kisah perumpamaan. Para sufi seperti Al-'Attar, Rumi, Sa'di mengajarkan kearifan perenial

${ }^{15}$ Jalaluddin Rakhmat, Belajar Cerdas, MLC, 2005, hlm. 17. 
dengan cerita. Plato berkata "pada sentuhan cinta semua orang menjadi pujangga", orang tua dapat berkata "pada sentuhan puisi semua orang menjadi pecinta." Selain membaca, upaya melihat tayangan-tayangan bernuansa religius sangat efektif dalam upaya pendidikan anak ini. ${ }^{16}$

\section{c. Menerangkan yang baik-baik}

“Dari Nuwas bin Sam'an, ia berkata: saya kepada Rasulullah SAW tentang kebaikan dan kejahatan, maka sabdanya:"kebaikan itu ialah perangai yang baik dan kejahatan itu ialah sesuatu yang beredar dihatimu dan engkau tidak suka diketahui oleh manusia". ${ }^{17}$ Di antara perkara baik-baik yang perlu diterangkan kepada anak adalah: (a) akidah (b) ibadah, (c) akhlak (d) menuntut ilmu, (e) janji-janji Allah kepada mereka yang berbuat baik dan (f) tentu masih banyak lagi seandainya orang tua tidak berilmu atau tidak pandai menerangkan maka seyogyanya ia mengundang orang lain secara periodik untuk menerangkan hal-hal tersebut kepada anaknya di rumahnya, atau menyerahkan anaknya untuk diajar oleh guru-guru agama Diniyah, pesantren, madrasah atau lainnya.

\footnotetext{
${ }^{16}$ Lihat penjelasan lebih detail dalam Milly R. Sonneman, Mahir Berbahasa Visual, Bandung, Kaifa, 2002.

17،Muslim mengambil hadits ini dari jalur Muhammad bin Hatim bin Maimun, diceritakan dari Mahdi dari Mu'awiyah bin Shaleh dari 'Abdurrahman bin Jabir bin Nafir dari bapaknya dari Nuwas bin Sam'an al-Anshari dari Nabi SAW". Selain dari Jalur Muhammad bin Hatim, Hadiis ini juga diriwayatkan melalui jalur Harun bin Su'aid al-Aili dari 'Abdullah bin Wahab dan Mu'awiyah, jalur ke atasnya sama seperti di atas, dengan redaksi hadits yang sama pula. Shahih Muslim, op.cit., Juz-2, Bab Tafsir al-biru wa alitsmu, hlm. 421
}

\section{Metode Keteladanan (al-Qudwah al- Hasanah)}

Orang tua adalah guru dan orang terdekat bagi si anak yang harus menjadi panutan. Karenanya, orang tua dituntut untuk bekerja keras untuk memberikan contoh dalam memelihara ketaatan serta ketekunan dalam beribadah dan beramal salih, serta anak akan mudah diingatkan secara sukarela. ${ }^{18}$ Hendaklah kedua orang tua menjadi teladan yang baik bagi anak dari permulaan kehidupannya, yaitu dengan menetapi manhaj Islam dalam perilaku mereka secara umum dan dalam pergaulannya dengan anak secara khusus. Sabda Nabi SAW:

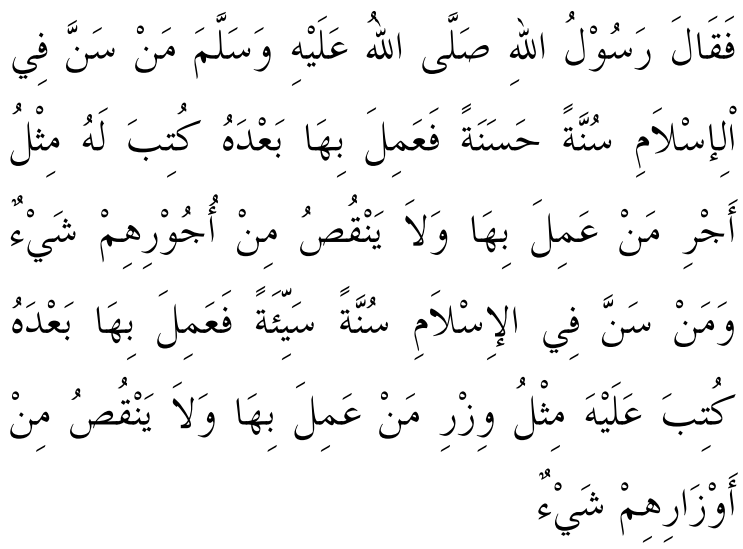

Barang siapa yang memberikan contoh yang baik dalam Islam maka baginya pahala atas perbuatan baiknya dan pahala orang-orang yang mengikutinya hingga hari kiamat. Yang demikian itu tidak menghalangi pahala orang-orang yang mengikutinya sedikitpun. Dan barang siapa yang memberikan contoh yang buruk didalam Islam maka baginya dosa atas perbuatannya dan dosa orang-orang yang mengikutinya hingga hari kiamat. Yang demikian itu tanpa mengurangi sedikitpun dosa orang-orang yang mengikutinya". (HR. Muslim)

${ }^{18}$ Muhammad al-Zuhaili, Menciptakan Remaja Dambaan Allah: Panduan Bagi Orang Tua Muslim, Bandung, al-Bayan, 2004, 83-84. 
Untuk mampu menjadi tauladan yang baik (uswatun hasanah), syarat utama adalah orang tua harus memahami Islam secara menyeluruh. Bagi yang belum memahami Islam, mempelajari Islam menjadi prioritas agar orang tua menjadi uswah hasanah. Beberapa hal keteladanan yang harus diperlihatkan terhadap anakanak. Pertama, Keharmonisan Rumah Tangga. Keharmonisan sebenarnya bukan hanya sebatas sebagai metode pendidikan akan tetapi secara umum merupakan dasar tujuan dari tujuan rumah tangga, namun keharmonisan dalam rumah tangga mengandung nilai edukatif bagi pembinaan keharmonisan anak anak, paraktek kaharmonisan akan tercermin dari seluruh aspek kehidupan rumah tangga, wujud keharmonisan ini terlihat dari saling menghormati dan saling menghargai antara suami istri, saling menyayangi, menjalin komunikasi diantara anggota rumah tangga, dan lain lain. Kedua, saling menolong antara suami-istri. Saling menolong merupakan sebuah cerminan dari akhlak Islami, dan merupakan kegiatan yang sangat dianjurkan dalam kehidupan sehari-hari. Dalam kehidupan berumah tangga dibutuhkan adanya kerja sama antara suami dan istri dalam melaksanakan berbagai aktifitas di lingkungan keluarga, jika diantara seorang suami dan istri tidak mempunyai rasa saling tolong menolong, maka maka tidak akan terjalinnya kekompakan dalam rumah tangga, sehingga akan sangat mempengaruhi proses perkembangan jiwa anak. Ketiga, Senang beramal dan beribadah. Ibadah dan beramal shaleh pada hakekatnya adalah kewajiban bagi setiap muslim, namun di lain pihak ia akan menjadi metode pendidikan yang baik karena akan menjadi teladan bagi anakanaknya.

Keempat, bergaul baik dengan tetangga. Manusia sebagai mahluk sosial, pasti akan membutuhkan orang lain atau kelompok. kelompok yang secara langsung berinteraksi dengan keluarga adalah tetangga. Banyak hal yang langsung atau tidak langsung keluarga berinteraksi dengan keluarga. Dengan kelompok mereka dapat bergotong royong bekerja sama menyelesaikan masalah-masalah yang menyangkut kepentingan masyarakat. Rasulullah bersabda, "Apabila engkau masak lauk, banyakanlah kuahnya dan hadiahkanlah kepada keluargamu".

\section{Metode Pembiasaan yang Baik (al- Taqwîd al-Hasanah)}

Para orang tua hendaklah mengetahui dan memilah-milah terhadap berbagai materi pendidikan anak yang mana harus lebih ajarkan melalui teladan, yang mana meteri yang harus diajarkan melalui pembiasaan. Karena setiap materi pendidikan itu memiliki karakter dan kekhususan yang berbeda-beda. Mendidik anak untuk mencapai keterampilan tertentu, kemantapan, kebenaran serta ketepatan bcribadah dan sebagainya, tidaklah cukup dengan hanya membari contoh dan teladan yang baik saja, akan tetapi harus diikuti dengan pembiasaanpembiasaan, yang dimulai sejak dini dan masa belajar anak terutama ketika anak masih berada dalam lingkungan pendidikan keluarga. ${ }^{19}$ Hal tersebut tidak hanya cukup dengan melakukan

${ }^{19}$ Izzah Iwadh Khalifah, Kiat Mendidik Anak, terjemahan Rahmat Nurhadi, Jakarta, Pustaka Islami, 2004, hlm. 55; Lihat juga Abdullah Nasikh Ulwan, Tarbiyah al-Aulad di Islam, hlm. 62 
pendekatan dan pemberian contoh tetapi harus menjadi suatu kebiasaan yang tidak lagi menjadi suatu paksaan.

Islam mengajarkan agar setiap manusia rajin bekerja, baik untuk mencapai kebahagiaan di akhirat maupun untuk memperoleh kesenangan dunia, bahkan mengharuskan agar setiap orang mengisi waktunya dengan perbuatan baik (al a'mâl al-shâlihah). Mengenai pengisian waktu senggang yang banyak dipermasalahkan orang dewasa ini, sebenarnya Islam telah mengaturnya, yaitu dengan melaksanakan berbagai kegiatan yang disamping berguna bagi individu yang bersangkutan juga bermanfaat bagi masyarakat; di antara kegiatan itu adalah; mencari nafkah hidup, menambah ilmu pengetahuan, membacaa al-Qur'an, mendirikan shalat sunat, bertasbih, berdzikir, dan sebagainya.

\section{Metode Pembelajaran Langsung}

Metode pembelajaran langsung dimaksudkan agar anak mempunyai pengalaman yang dirasakannya sendiri atau dipahami sendiri. Misalnya, orang tua membawa anak untuk menikmati keindahan alam. Teknologi moderen dan kehidupan urban membuat manusia teralienasi dari alam, yakni setiap manusia tidak akrab lagi dengan alam. Setiap hari mayoritas manusia berhubungan dengan alam yang sudah dicemari, dimanipulasi, dirusak. Alam tampak di depan manusia sebagai musuh setelah manusia mengeksploitasinya. Orang tua dapat mendekatkan anak-anak kepada alam yang relatif belum banyak tercemari. Orang tua dan anak harus menyediakan waktu khusus bersama mereka untuk menikmati ciptaan Tuhan, setelah setiap hari manusia dipengapkan oleh ciptaan manusia sendiri. Misalnya, mengajak naik ke puncak gunung, merasakan udara yang segar dan sejuk, mendengarkan burung-burung yang berkicau dengan bebas, menghirup wewangian alami, dan seterusnya. Sejalan dengan hal tersebut, ikut-sertakan anak dalam kegiatan-kegiatan sosial.

\section{Metode Penghargaan dan Hukuman}

Menghukum anak kadang-kadang perlu, karena berbagi pendidikan dan bimbingan yang orang tua terapkan ada anak-anaknya sering kali terjadi pelanggaran atau kebiasaan anak yang selalu cenderung melawan dan menentang terhadap perintah orang tuanya. Dalam kasus seperti ini memberikan hukuman menjadi wajar dan agar anak menjadi ta'at. Memberi maaf yang berlebihan akan memberi peluang bagi anak untuk melakukan kesalahan serupa atau yang lebih besar. Mereka juga akan mengira bahwa masyarakat di luar rumah akan memperlakukan hal yang sama seperti yang dilakukan ole orang tuanya. Ini jelas akan menurunkan kecerdasan emosional anak. $^{20}$

Dalam melaksanakan hukuman orang tua memperhatikan ketentuan ketentuan sebagai berikut: Pertama, Ketentuan umum, hukuman tidak boleh dilakukan kecuali karena kondisi terpaksa atau bila diperlukan. Hukuman pukulan tidak boleh dilakukan kecuali setelah hukuman lain yang lebih bersifat ringan; Kedua, Ketentuan khusus, yaitu orang tua harus mempelajari motivasi kenakalan anaknya sebelum menjatuhkan hukuman. Hal itu

${ }^{20}$ Suhailah Zainul Abidin Hammad, Menuai Kasih Sayang di Tengah Keluarga, terjemahan Ayub Muraslin, Jakarta, Mustaqim, 2002, hlm. 145. 
perlu karena akan sangat menentukan jenis dan bentuk hukuman yang akan diberikan, juga orang tua akan dapat menghilangkan berbagai motivasi yang menyebabkan anak itu berbuat salah. Orang tua juga harus memperhatikan beberapa hal, yakni:

Pertama, Adalah buruk memarahi tanpa memberikan penjelasan. Sekali waktu orang tua perlu duduk bersama dalam suasana yang mesra dengan anak untuk berbicara tentang aturan-aturan; Kedua, orang tua dapat membuat komitmen bersama dengan anak untuk mematuhi aturan. Misalnya, mintalah kepada anak agar tenang ketika ada tamu. Kalau ada yang perlu disampaikan, atau anak menginginkan sesuatu, hendaknya menyampaikan kepada orang tua dengan baik-baik dan bersabar bila belum dapat memenuhinya. Bersama dengan komitmen ini orang tua dapat membicarakan dengan anak konsekuensi apa yang dapat diterima bila anak mengamuk di saat ada tamu. Konsekuensi ini disampaikan dengan nada yang akrab. Bukan ancaman. Bila anak melakukan hal-hal negatif yang sangat mengganggu, orang tua dapat mengingatkan kembali kepada anak dan lagi-lagi tidak dengan nada mengancam. ${ }^{21}$

Salah satu kebiasaan umum orang tua yang menyakitkan hati anak sehingga dapat melemahkan citra dirinya adalah ungkapan, "Ibu/Bapak sudah berkali-kali bilang, tapi kamu tidak mau mendengarkan." Ungkapan ini memang efektif untuk membuat anak diam menunduk. Tetapi ia diam karena harga dirinya jatuh, bukan karena menyadari kesalahan. Jika ini sering terjadi, anak akan memiliki citra diri yang buruk. Dampak

\footnotetext{
${ }^{21}$ Najib Khalid al-Am, Mendidik Cara Nabi saw., Bandung, Pustaka Hidayah, 1990, hlm. 21-22.
}

selanjutnya, konsep diri dan harga diri (self esteem) anak akan lemah. Anak melihat belajar memandang dirinya secara negatif, sehingga lupa dengan berbagai kebaikan dan keunggulan yang ia miliki. Sebaliknya orang tua juga demikian, semakin sering berkata seperti itu kepada anak, maka orang tua akan semakin mudah bereaksi secara impulsif.

Orang tua semakin percaya pada anggapan sendiri bahwa anak-anaknya memang bandel, menjengkelkan, dan susah dinasehati. Kebiasaan memarahi anak dengan ungkapan "Bapak kan sudah bilang berkali-kali" atau yang sejenis dengan itu, harus dikikis secara sadar dari sekarang. Orang tua perlu menguatkan tekad untuk berkata yang lebih positif, betapa pun hampir setiap komentar orang tua masih buruk. Orang tua sangat perlu untuk mengetahui bagaimana langkah-langkah Hukuman itu dilaksanakan, sebab penerapan hukuman yang salah atau asalasalan selalu tidak akan memberikan hasil bagi pendidikan anak akan tetapi dapat memberikan dampak lebih buruk kepada tingkah laku dan kejiwaan anak. ${ }^{22}$

\footnotetext{
${ }^{22}$ Para Ahli pendidikan telah mengatur urutan hukuman dengan pukulan, dengan berpedoman bimbingan Nabi SAW sebagai berikut: a) Tidak boleh terburu-buru menghukum dengan pukulan, kecuali setelah hukuman bentuk lainnya tidak bermakna lagi; b) Tidak boleh melakukan hukuman (pukulan) dalam keadaan sedang marah, karena bila dilakukan dengan marah pelaksanaanya dapat tidak tcrkendali dan melampaui batas; c) Pukulan tidak boleh mengenai bagian-hagian yang vital dan membahayakan keselamatan anak; d) Pada pukulan pertama hendaknya yang ringan-ringan saja dan tidak boleh terlalu banyak untuk sekali hukuman; e) Hukuman tidak boleh dikenakan pada anak yang tidak mencapai usia 10 tahun; f) Pukulan terhadap anak harus dilakukan oleh orang tua sendiri tidak boleh oleh orang lain, karena secara hukum orang tualah yang berhak mendidik anaknya secara langsung; g) Apabila anak sudah hampir mendekati
} 


\section{Penutup}

Terdapat beberapa metode yang dapat diterapkan oleh keluarga untuk memaksimalkan potensi keluarga untuk membentuk multikecerdasan (ESQ) anak.

Dalam pelaksanaan proses pendidikan anak, metode yang diterapkan haruslah bervariasi sesuai dengan kebutuhan, situasi, kondisi, tempat, dan waktu si anak. Metode yang dimaksud terdiri dari 1) Metode pembelajaran komunikatif, 2) Metode keteladanan, 3) Metode pembiasaan, 4) Metode pembelajaran langsung, dan 5) metode penghargaan dan hukuman. Langkah-langkah keluarga dalam upaya mewujudkan kecerdasan emosional menurut pendidikan islam dapat mengikuti langkah-langkah tertentu seperti yang diajarkan oleh Islam tentang pendidikan anak. Langkah-langkah tersebut adalah: (1) langkah-langkah persiapan melalui pembinaan lingkungan Islami; (2) langkah-langkah pelaksanaan pendidikan anak pra-natal (masih dalam kandungan); (3) langkah-langkah pelaksanaan pendidikan anak setelah lahir pra-remaja; (4) langkah pendampingan di masa anak sudah menginjak dewasa.

usia baligh dan ia masih membandel, maka pukulan boleh lebih dari 10x. (lihat Muhammad Syarif AshShawwaf, ABG Islami: Kiat-Kiat Efektif Mendidik Anak dan Remaja, Bandung, Pustaka Hidayah, 2003, hlm.146.

\section{DAFTAR PUSTAKA}

Abd al-Rahmân al-Nahlawi, Pendidikan Islam di Rumah, Sekolah, dan Masyarakat, terjemahan oleh Sihabuddin, Jakarta, Gema Insani Press, 1995.

Abu Ahmadi, Ilmu Pendidikan, Jakarta: Rineka Cipta, 1991

Bobbi DePorter, Quantum Learning, Bandung, Kaifa, 1999.

Dimyati dan Mudjiono, Belajar dan Pembelajaran, Jakarta, Rineka Cipta dan Depdikbud, 2002

Depdikbud, Kamus Besar Bahasa Indonesia, Jakarta: Balai Pustaka, 1990), cet ke-3

Izzah Iwadh Khalifah, Kiat Mendidik Anak, terjemahan Rahmat Nurhadi, Jakarta, Pustaka Islami, 2004,

Muhammad Syarif Ash- Shawwaf, $A B G$ Islami: Kiat-Kiat Efektif Mendidik Anak dan Remaja, Bandung, Pustaka Hidayah, 2003,

Muhammad al-Zuhaili, Menciptakan Remaja Dambaan Allah: Panduan Bagi Orang Tua Muslim, Bandung, al-Bayan, 2004,

Muhammad Fu'ad Abd al-Baqî, Mu'jam al-Mufahrats li Alfadz al-Qur'ân alKarîm, Angkasa, t.t.

Najib Khalid al-Am, Mendidik Cara Nabi saw., Bandung, Pustaka Hidayah, 1990

Suhailah Zainul Abidin Hammad, Menuai Kasih Sayang di Tengah Keluarga, terjemahan Ayub Muraslin, Jakarta, Mustaqim, 2002. 
Ramayulis dkk, Pendidikan Islam dalam Rumah Tangga, Jakarta, Kalam Mulia, 1996,

Zakiyah Darajat, Berawal dari Keluarga: Revolusi Belajar Cara al-Qur'an, Jakarta, Hikmah, 2002, cetakan ke-1,

Zakiyah Darajat, Kepribadian Guru, Jakarta, Bulan Bintang, 1980. 